\title{
Inclusion of an Integrated Team Based Learning Session in First Year Histology is well Received, but who Fares well and who Benefits?
}

\author{
Isaac Van Sligtenhorst ${ }^{1}$ and Roger J. Bick*,2 \\ ${ }^{1}$ University of Texas Medical School at Houston and ${ }^{2}$ Dept. of Pathology, University of Texas Health Science Center, \\ Houston, Texas 77030, USA
}

\begin{abstract}
Integrated teaching in medical school instruction has become a much favoured and desired method of education practice, and variety in curricula has become a topic of much discussion, as well as the practice of including stimulating, student-centered projects in lectures and labs, which is now common place. These changes appear to help students in their study routines and learning outcomes.

There has been success at this medical school with the construction of a team-based learning (TBL) program termed Clinical Applications, which is part of the Introduction to Clinical medicine course. Because of this success, it was decided to include three TBL sessions in the histology and cell biology course, our hypothesis being that these additions would invigorate students, give them a head start for their clinical studies, encourage fruitful interactions, while developing positive attitudes.

Students formed small groups in the histology and cell biology course and microscopically examined designated slides from their issued collections. These slides were compared to a 'case' slide and that each group discussed their findings with the aid of their syllabus, lecture material and atlas.

Evaluations of TBL sessions were mixed, but positive feedback was much more apparent than negative input, with group size and slides issued being the main concerns. Feedback was from answers on end of course evaluations, and it was of interest to note that students who did attend lectures and labs on a regular basis were better able to decipher the 'case' slides, while often helping other, less prepared students, so some students benefited from the insights by regular attendees, while others were refocused via the macroscopic changes.

Evaluation comments noted that sessions were beneficial due to their integrative structure, the increased peer-peer interactions, overall attitude improvements, leadership development and having a 'real-life' exercise, revealing this course innovation as something to be developed.
\end{abstract}

Keywords: Course development, integrative teaching, histology, competency.

\section{INTRODUCTION}

Focused reasoning, clinical reasoning and problem based learning has its roots in the work of Abraham Flexnor [1]. However, in a recent report on medical education and its development, the authors begin the piece by stating, "Medical education seems to be in a perpetual state of unrest" [2]. This often does seem the case with conflicting outcomes, such as web based courses being reported as beneficial in one medical school, while not in another. Or, small group teaching yielding positive results for one group of faculty, but not for another [3,4].

A relatively recent paper addressed team-based learning (TBL) and its group dynamics [5] and as TBL is increasing in popularity while yielding a seemingly endless supply of positive outcomes, it was no surprise when Miller and colleagues concluded that 'inter-professional education' should be introduced early and should be continuous, leading to better care due to idea exchanges and competency based

*Address correspondence to this author at the Department of Pathology, MSB 2.288, TMSH, 6431 Fannin Street, Houston, Texas 77030, USA; Tel:

713-500-5406; Fax: 713-500-0730; E-mail: Roger.J.Bick@uth.tmc.edu methodologies [6]. That theme is seen throughout many present day courses and in many publications [7]. Coupled with clinical and evidence-based examples, basic sciences, whether TBL and/or peer other evaluation mechanisms are included or not, it is now widely accepted that TBL yields many benefits and is a highly utilized mode of teaching.

Therefore, we wanted to determine if TBL was of benefit to most students and if it was well accepted by the majority of students, while determining if inclusion of a mandatory, interactive lab session resulted in changes in students' attitudes and other improvements. Our evidence indicates that TBL is a mode of teaching that should be increasingly included in curricula due to it multiple benefits.

There have been a number of recent 'trials' in medical education regarding the benefits of team based learning (TBL) in an integrative curriculum [8]. Most, if not all, of the ensuing reports have stressed an overall positive outcome, particularly as students pass through the first years and move into clinical scenarios [9].

However, there have been some, possibly unforeseen, beneficial outcomes from using TBL. Chung and colleagues [10] noted the difficulty in convincing students that the study 
of medical ethics wasn't a waste of time, and in their TBLbased session using GRATs and IRATS such as we incorporated in our Clinical Applications course [11, 12], they found that students were happier studying by this method. Parmelee and Michaelsen [13] recently published a 'list' for constructing and delivering a TBL experience that enhances the students' time in the basic science years of medical school, while encouraging "deep thinking", promoting good behaviour (bad attitude reversal) and introducing many students to self and peer evaluation. One important observation which was noted previously [14] was that the ablest students tended to benefit more from the TBL exercises, as they were able to easily apply basic science knowledge to pathologic samples, thereby performing a rudimentary diagnosis in their second month of medical school. These studies often resulted in emailed questions to instructors from students following further research which indicated continued interest in the topic and individual, unassigned study. We also believe it fair to assume that some students improved their overall performance throughout the course due to the group sessions and input from their "more able" classmates [15].

\section{MATERIALS AND METHODOLOGY}

Each year the intake of students at this medical school is approximately 240. The students are assigned bench space for labs and the TBL groups are based on this assignment (30 groups of 8 students). The Histology and Cell Biology course follows the accepted progression of teaching and study from cell biology, through epithelium and glands, tissues and complex systems. The material is divided into three blocks, with a multiple choice question exam in both written and image formats at the end of each block. In each block one topic is selected as a TBL session. In their assigned groups students microscopically examine designated slides from their issued collections. A 'case' slide is then furnished so that each group can compare this slide with their normal slides, initiating discussions, and generating answers to complete the question sheet, A maximum of 5 points are available to each member of each group towards their block grade. Students are allowed to use their syllabus, lecture material, and histology atlas.

Although labs and lectures are not mandatory attendance TBL sessions are and, as stated previously, each session each student can earn a maximum of 5 points towards their final block exam grade, and therefore points towards their final grade which is based on a cumulative total. The TBL sessions are structured such that the pathology slide has overt, easily identifiable differences, such as Hashimoto's disease and can therefore be easily contrasted with their assigned, normal slide (See TBL example).

\section{TBL EXAMPLE \\ MSI HISTOLOGY - BLOCK 2 - THYROID TEAM-BASED LEARNING LABORATORY SESSION \#2}

Given the information you have received in the lectures so far in the first two blocks plus, more importantly in today's lecture and lab, examine the tissue on the slide given to you by the instructor and answer the questions in your assigned group. You may refer to syllabus material and the recommended texts (Gartner and Hiatt). NO LAPTOPS!!!!!!!!!!!

Group \#

Please sign below. Should you neglect to sign, you will receive a score of ZERO. Receipt of signatures on this answer sheet attests that you were present throughout the entire lab and participated in group discussions. This is in fact an HONOR PLEDGE!

$\underline{\text { Name }}$

$\begin{array}{lll}\text { PRINT } & \text { SIGNATURE } & \text { TEST ID }\end{array}$

Question 1. Comparing and contrasting the second tissue with the tissue from your slide box (slide \#56), note 3 changes to the cellular content in this tissue (1 point)

1 .

2 .

3.

Question 2. Look at the structure and size of the follicles and decide which one of the following is true (2 points)

This tissue is hypoactive

This tissue is hyperactive

This tissue has normal activity

JUSTIFY YOUR CHOICE! 


\section{Question 3. (2 points)}

It should be evident that there are a number of cell types present that are not normally seen in this tissue in the large numbers shown. List the cells types that you consider are not normally found in such large numbers in this tissue. Describe in 2-3 sentences what kind of problem is probably occurring?

You have 30 minutes to complete this task. Failure to hand in this paper during the lab session will result in a grade of zero. This TBL-test will constitute $\underline{5 \%}$ of your final block grade. Failure to attend this mandatory session will result in a score of zero being assessed for this and subsequent TBL lab sessions.

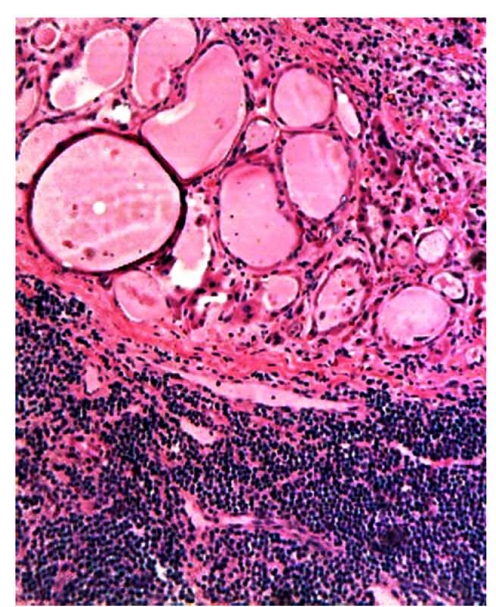

HASHIMOTOS

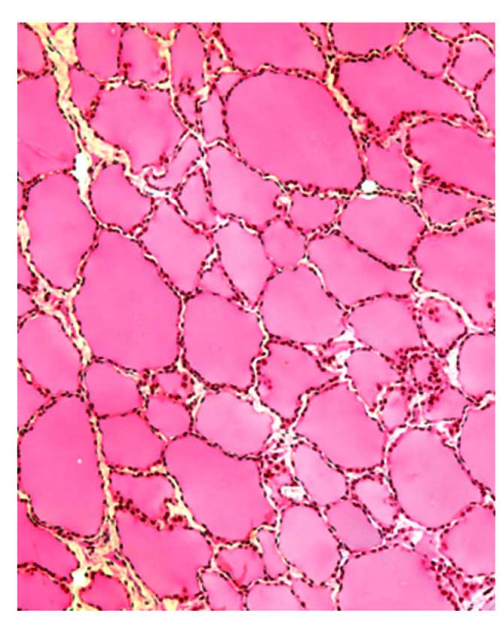

NORMAL

Fig. (1). Example of a TBL exercise for first year medical students in histology and cell biology lab. Note that the questions are brief and structural and cellular changes are very evident as seen in the two images from a normal and Hashimoto's thyroid.

The completed answer sheet is signed by each group member (an honour pledge) and returned for grading. A post lab wrap-up session of objectives and goals for that day's topic is delivered and the TBL session is then discussed in depth by an expert in that field, noting the clinical importance of the cells and tissues involved. Reasons for the assigned grade, if needed, are posted on Blackboard ${ }^{\mathrm{TM}}$ (Blackboard Inc., Washington DC, USA) by the instructor, allowing for rapid feedback and interchanges between students and faculty.

At the end of the histology and cell biology course students were asked to complete an online evaluation using One 45 software (one45 Software, Vancouver, British Columbia, Canada) and responses remained anonymous. While this evaluation procedure has been in place for the past 2 years, the findings and observations reported here are only from the last academic year (2010-11), as it was felt that set up familiarity might have possibly caused some reporting problems. However, results years were compared observe patterns and percentages, and these were statistically similar. In fact, the response percent was the same, and the comments were comparable. Any 'unsavory' responses were not considered in the final interpretations, and were removed

\section{RESULTS}

Multiple benefits were seen from the introduction of these TBL group studies. Benefits to the faculty are that only 30 answer sheets require grading and, as the questions are focused on topics that faculty describe as "very evident differences/pathologies", the time required for grading is short. Answers gave faculty at least a superficial idea as to
Answers gave faculty at least a superficial idea as to the overall abilities of the class and any attitude problems.

Students were seen to interact to a much greater with their peers in these TBL sessions when compared to "normal' lab and the feedback has been, for the most part, very positive. Students had the opportunity to evaluate and critique the course anonymously, replying to two questions; 1. Did the TBL sessions increase your interactions with other students?; 2, Did TBL increase your understanding as to the pathologic changes regarding the daily topics? There were 78 replies to each question (33.77\%; 78 of 231 students) with a variety of comments as shown here for Q1:

- It was very hard to coordinate discussion amongst the group in the lab setting since we were all in a straight line. Better grouping might have one row turn and face the one behind it. Also, the key to getting the extra '6th point' was noting the possibility of macrophages and lipofuscin in the infarcted tissue. While I am sure that some of the groups did come up with this point, if you good at the grade distribution and where those groups are located, most of the ones that received the extra point are in the same lab section and near each other in lab - suggesting that someone had a realization, announced it and other groups heard the idea. Somehow mitigating this problem would be beneficial. In addition, when talking with other students, there is a vast difference in the usefulness of the laboratory sections. What I mean is that some of the lab leaders are more useful in teaching than others. Dr. $* * * * * * * *$ would go through all the images, giving points and talking about them. While my lab leader, would typically not say anything or just walk around answering questions. I think I would get more out of the lab if we all had that instruction. 
- Yes, there were a lot of ideas and stuff being thrown around and evaluated.

- The TBL groups are too large and it is difficult to have everyone participate. The groups are so large that everyone barely gets to look at the slide and it is difficult to come up with an agreement in the allotted time.

- It was a good work out for learning to work as a team to figure out the solution to a problem.

- Only during the session.

- The TBL didn't really increase my learning

- It did increase interactions with other students - but still felt that the group size ( 6) was too large. It was difficult to get each person's input and to share time with the path. slide such that each student could contribute useful input regarding their observations, etc.

- The TBL sessions are a good idea but the groups are too large for it to work effectively. Having a group of four would be much more efficient than a group of 8 ; in a group of 8 , you tend to have at least 3 people who are just standing around doing nothing because there is not enough room and only one slide.

- Worked with several students, but turned into half of the group doing the work without even speaking/consulting with the second half.

- $\quad$ Enjoyed TBL- good practice for working with other (future) physicians.....and it was fun/helpful to have the chance to integrate

\section{And here to Q2:}

- To a limited extent since we only focused on the one image.

- Seeing the diseased tissue was helpful in distinguishing between what's normal and what isn't.

- I enjoyed the TBL because it related histology a common pathologic incidence.

- Dr. $* * * * * *$ and Dr. $* * * * * * * * * * *$ are phenomenal instructors, making TBL a great experience

- $\quad$ Absolutely

- Yep, although more diseased tissue examples would not only be relevant, but may serve to reinforce our understanding of proper tissue structure and function.

- Yes. I thought the TBL practice was helpful and practical.

- HAVE MORE OF THEM (TBL's). ONE IS NOT ENOUGH.

- Seeing an abnormal slide to compare with was rather enjoyable!

- Was too limited to apply elsewhere.

Student concerns were mostly with group size and the number of pathology slides issued. However, economics and lab construction played some part in these dislikes, and the course constructs did, by and large, maintain student-student interactions. Very positive answers such as, "HAVE MORE OF THEM. ONE IS NOT ENOUGH", and "Yes, there were a lot of ideas and stuff being thrown around and evaluated", made the feedback not only informative, but an inducement for development of these sessions. In fact, some students who admitted to having problems in cell and tissue identification, commented that these exercises helped and that intergroup discussions aided them in organelle, cell and tissue recognition. A few students subsequently mentioned that these exercises helped in their Clinical Applications classes and in their second year Problem Based Learning groups e.g. "After doing tons of questions for step and studying path, I would like to thank you for teaching us histology lab, as having learned in lab how to identify things by appearancelfeatures rather than memorizing pictures, I can try to figure things out just by how it looks, even if I haven't seen that particular pathology before. Great stuff".

Each topic had an associated, clinic correlate in the postlab discussion, as it was obviously important to stress the clinical relevance of each topic after the exercise. Students were also asked to evaluate these sessions by answering the question, "Did the clinical correlations give you a better idea of the involvement of basic cells and structures in disease". Seventy seven students answered this question (33\%), with selected comments shown here:

- They were interesting to give us a better idea of the stuff, but I'm glad it is not on the exams. I think having to learn the pathology at this point would be difficult.

- The Clinical Correlates were a fascinating addition to the lecture and post lab material.

- $\quad$ I... I think so. This is about TBLs, right? Exam week hurt brain. I apologize.

- I enjoyed them!

- The clinical correlations did help, but the cases were often rushed over by the lecturers. Some CC's were not well tied into the lecture and did not seem very relevant.

- It's pretty hard to feel connected with stuff you can only see with a microscope, but seeing how they actually affect the body in a macroscopic way helps a lot.

- Was so focused on one tissue and organ. We have pathology later on, but clinical correlate lectures would be wonderful and a change in pace

Once again, the overall feedback was positive with the perception that information from the topic segments (lecture, lab/TBL, post lab/clinical correlate) helped put things into perspective. Thus, TBL sessions received sufficient positive feedback from both students and faculty members that they were also introduced into the dental school general histology course and the medical school immunology course. TBL classes resulted in i) vertical learning via clinical scenarios and skills in a basic science course and ii) horizontal learning via development of skills for use in PBL, Fundamentals of Clinical Medicine and the presentation of clinical correlations and integrations [16, 17]. This was appreciated by many students and overcame some of the resentment to the 'mandatory' aspect of TBL, in that the students were aware that basic science classes were constructed and focused towards their future clinical needs and understanding.

Possibly the most beneficial result of these TBL sessions, was that students who were performing below their capabilities became more aware of their shortcomings and came to grips with the fact that it was not in their best interest to 
learn medicine solely via websites and other electronic resources, while forsaking valuable interactions with their peers and faculty. A few students did resent the fact that this particular part of their course was mandatory attendance, and demonstrated a bad attitude and an anti-team approach in their studies. These 'drawbacks' became less evident as TBL cases progressed.

Negatives did occur. Evaluations were made anonymously, giving some students, probably those that resented the mandatory attendance of TBL labs, the chance to write childish and spiteful comments. Perhaps each student should add their name to posted comments allowing for faculty and administrators to correct attitude problems. However, over the past two years, $84.6 \pm 1.3 \%$ of the students gave positive replies $(47.9 \pm 2.6 \%$ evaluation return).

There is a need for enthusiastic and available faculty members to oversee the group sessions. Some students suggested that one slide per group was not sufficient. However, when more slides were issued, group members drifted apart and interactions between all of the members was reduced. Finally, it is obvious that some groups would be stronger in their cognitive and reasoning abilities and 'weaker' members would benefit. However, the positives outweigh this negative and awarding a maximum of five points did not make final grades undergo major changes.

Overall, inclusion of TBL in our Histology and Cell Biology course was a positive, rewarding, and challenging experience for the majority of the students and increased student-student and student-faculty interactions without dependence on electronic resources, hopefully acting as a precursor to further study via Web-based resources [18]. There are both drawbacks and new ideas emerging from this study as to how observations and outcomes from these TBL sessions need further dissection. Such as, for those students that regularly attended the non-mandatory lab and lectures, the TBL sessions were seen as exciting and rewarding, and a welcome addition to the curriculum. However, for some of those students that were not regular attendees at lab and lecture, and who used web resources and the UT Learning Resource Center to a great extent, the TBL sessions were seen as time consuming; some students were less appreciative of the efforts of the faculty and their classmates; some students exhibited a poor attitude; a few students struggled to integrate delivered information into the 'case' topics.

\section{DISCUSSION}

Real world learning is seldom, if ever, in a strictly didactic form. However, much of the first two years of medical school is often still lecture based with at least a partial necessity to learn by rote without critical thinking. TBL mimics a lot of CME scenarios and allows not only students but also faculty the chance to apply knowledge to actual cases, thereby immediately understanding the concepts and mechanisms involved. Incorporating TBL into courses brings with it both pros and cons, but the format tends to lessen the stark demarcation that occurs between grades of the students that excel and those that struggle to pass. Proving that a student memorized the syllabus should not be the aim of teaching at any level, and TBL ensures, one hopes, demonstrates that the student applies basic science facts and knowledge in context, rather than in abstract terms, and becomes a critical thinker, paramount in the development of a good physician.

There are the inevitable negatives. A number of students prefer to study in our learning resource center and therefore rely on web-based information and resources, Blackboard ${ }^{\mathrm{TM}}$ and the course home page. They resent the 'extra' time they must spend in lab. Some students found it "difficult" to work with their assigned group, but this might be beneficial to them in terms of personal development. A few students were concerned that some group members were "not pulling their weight", but the upside is that the 'better' students help the less accomplished. Finally, the group size ( 7 to 8 students) was considered too large by many. However, the interactions were obvious, welcome and pleasing.

Some students displayed a poor attitude when given 'mandatory' tasks as stated, and this was a very disappointing problem. It was also evident that those students who attended labs in particular, and lectures to a large extent, had a better ability in applying their histology learning's to pathologic tissues and cells, in an early, insightful manner. We must therefore ask ourselves if TBL should be used in other ways given the aforementioned "unforeseen benefits". Would it be a benefit to low scoring/failing students to take only TBL-based remediation classes when offered? Should attitude concerns that occur during TBL sessions be noted as part of a students' permanent record, or should they be directed to a member of faculty, an action that might make them angry? Should TBL groups be formed based, as much as possible, on a designed mixture of high scoring and low scoring students? How much of the basic science years/courses should be mandatory attendance?

Many questions remain and in the very near future we will know how well TBL works. Early signs show much promise and now it is decision making time as to how, when and where TBL is integrated into education, and how much of traditional education methodologies are removed or lessened to accommodate team-based learning [11, 19]. In fact, the introduction of broad spectrum learning in anatomy has been suggested in studying anatomy, such that a students' attitude is "healthy" and incorporates "self reflection" and critical thinking. ${ }^{4}$ Further, it has been suggested that in postbasic science years, and clinically-oriented classes, simulation, critical thinking and real life, integrative exercises need to become a greater part of study methods than "cookbook" methodology [20, 21].

It would therefore behoove course directors and education administrators to take these observations from group studies into consideration for student promotions and evaluations and consider where similar learning experiences can be introduced into a medical school curriculum [10].

\section{CONFLICT OF INTEREST}

None declared.

\section{ACKNOWLEDGEMENTS}

RJB wishes to thank Drs. Judianne Kellaway MD, Diane Hickson-Bick PhD, Barry Rittman PhD, Keri Smith PhD and Margaret Uthman MD, for their help and input in making these TBL sessions a success, and a special thanks to Marylee Kott MD for tissues; to Wai-San Johansson, M.Ed. 
and Brenda Bassham M.Ed., for their assistance with the evaluations and instruction for One45 (one45 Software, 509 Richards St, 3rd Floor, Vancouver, BC, V6B 2Z6) and Blackboard $^{\mathrm{TM}}$ (Blackboard Inc., 650 Massachusetts Avenue N.W., 6th Floor, Washington, DC 20001-3796 U.S.A.). Thanks also go to Mr. Hai Nguyen, MSII, and Elena Sutherland, MSI for their wonderful input as course representatives.

\section{REFERENCES}

[1] Flexnor A. A medical education in the United States and Canada Bulletin Number Four: a report to the Carnegie Foundation for the Advancement of Teaching. The Flexner Report. New York, NY: Carnegie Foundation 1910.

[2] Cooke M, Irby DM, Sullivan W, Ludmerer KM. American medical education 100 years after the Flexner report. N Engl J Med 2006; 3559: 1339-44.

[3] Colliver JA, Feltovich PJ, Verhulst SJ. Small group learning in medical education: a second look at the Springer, Stanne, and Donovan meta-analysis. Teach Learn Med 2003; 15: 2-5.

[4] Hammer RR. An education that pierces what the knife cannot: a student perspective. Anat Sci Educ 2010; 3: 151-3.

[5] Sweet M, Michaelsen LK. How group dynamics research can inform the theory and practice of postsecondary small group learning. Educ Psych Rev 2007; 19: 31-47.

[6] Miller BM, Moore DE Jr, Stead WW, Balser JR. Beyond Flexnor: a new model for continuous learning in the health professions. Acad Med 2010; 85: 266-72

[7] Gregory JK, Lachman N, Camp CL, Chen LP, Pawlina W. Restructuring a basic science course for core competencies: and example from anatomy teaching. Med Teach 2009; 31: 855-61.

[8] Parmelee DX, DeStephen D, Borges NJ. Medical students' attitudes about team-based learning in a pre-clinical curriculum. Med Educ Online 2009; 14: 1-6.

[9] Shafi R, Quadri KH, Ahmed W, Mahmud SN, Iqbal M. Experience with a theme-based integrated renal module for a second-year MBBS class. Adv Physiol Educ 2010; 34: 15-9.
[10] Chung EK, Rhee JA, Baik YH, A OS. The effect of team-based learning in medical ethics education. Med Teach 2009; 31: 1013-7.

[11] Bick RJ, Oakes JL, Actor JK, et al. Problem solving and integration of basic science concepts into clinical scenarios using teambased learning. J Int Assoc Med Sci Educ 2009; 19: 26-34.

[12] Seifert WE Jr, Actor JK, Bick RJ, et al. Clinical applications: Problem solving and integration of basic science concepts using teambased learning. J Int Assoc Med Sci Educ 2008; 18: 1S:4S.

[13] Parmelee DX, Michaelsen LK. Twelve tips for doing effective Team-Based Learning (TBL). Med Teach 2010; 32: 118-22.

[14] Wiener H, Plass H, Marz R. Team-based learning in intensive course format for first-year medical students. Croat Med J 2009; 50: 69-76.

[15] Zgheib NK, Simaan JA, Sabra R. Using team-based learning to teach pharmacology to second year medical students improves student performance. Med Teach 2010; 32: 130-5.

[16] Kingsley K, O’Malley S, Stewart T, Howard KM. Research enrichment: evaluation of structured research in the curriculum for dental medicine students as part of the vertical and horizontal integration of biomedical training and discovery. BMC Med Educ 2008; 19: 8-9.

[17] Van der Veken J, Valcke M, De Maeseneer J, Derese A. Impact of the transition from a conventional to an integrated contextual medical curriculum on students' learning patterns: a longitudinal study. Med Teach 2008; 31: 433-41.

[18] Black VH, Smith PR. Increasing active student participation in histology. Anat Rec B New Anat 2004; 278: 14-7.

[19] Abdelkhalek N, Hussein A, Gibbs T, Hamdy H. Using team-based learning to prepare medical students for future problem-based learning. Med Teach 2010: 32: 123-9.

[20] Sullivan DL, Chumbley C. Critical thinking a new approach to patient care. J Emerg Med Serv 2010; 35: 48-53.

[21] Rosenzweig M, Hravnak M, Magdic K, Beach M, Clifton M, Arnold R. Patient communication simulation laboratory for students in an acute care nurse practitioner program. Amer J Crit Care 2008; 17: 364-72.

(C) Sligtenhorst and Bick; Licensee Bentham Open

This is an open access article licensed under the terms of the Creative Commons Attribution Non-Commercial License (http://creativecommons.org/licenses/by-nc/3.0/) which permits unrestricted, non-commercial use, distribution and reproduction in any medium, provided the work is properly cited. 